\title{
The impact of diagenesis on the reservoir quality of the early Cretaceous Lower Goru sandstones in the Lower Indus Basin, Pakistan
}

\author{
Qamar UZ Zaman Dar ${ }^{1} \cdot$ Renhai $\mathrm{Pu}^{1} \cdot$ Christopher Baiyegunhi $^{2} \cdot$ Ghulam Shabeer $^{3} \cdot$ Rana Imran $\mathrm{Ali}^{4} \cdot$ Umar Ashraf $^{5}$. \\ Zulqarnain Sajid $^{6} \cdot$ Mubashir Mehmood $^{7}$
}

Received: 16 June 2021 / Accepted: 1 December 2021 / Published online: 8 December 2021

(c) The Author(s) 2021

\begin{abstract}
The sandstone units of the Early Cretaceous Lower Goru Formation are significant reservoir for gas, oil, and condensates in the Lower Indus Basin of Pakistan. Even though these sandstones are significant reservoir rocks for hydrocarbon exploration, the diagenetic controls on the reservoir properties of the sandstones are poorly documented. For effective exploration, production, and appraisal of a promising reservoir, the diagenesis and reservoir properties must be comprehensively analyzed first. For this study, core samples from depths of more than $3100 \mathrm{~m}$ from the KD-01 well within the central division of the basin have been studied. These sandstones were analyzed using petrographic, X-ray diffraction, and scanning electron microscopic analyses to unravel diagenetic impacts on reservoir properties of the sandstone. Medium to coarse-grained and well-sorted sandstone have been identified during petrographic study. The sandstone are categorized as arkose and lithic arkose. Principal diagenetic events which have resulted in changing the primary characters of the sandstones are compaction, cementation, dissolution, and mineral replacement. The observed diagenetic processes can be grouped into early, burial, and late diagenesis. Chlorite is the dominant diagenetic constituent that occurs as rims, coatings, and replacing grains. The early phase of coating of authigenic chlorite has preserved the primary porosity. The recrystallization of chlorite into chamosite has massively reduced the original pore space because of its bridging structure. The current study reveals that diagenetic processes have altered the original rock properties and reservoir characteristics of the Lower Goru sandstone. These preliminary outcomes of this study have great potential to improve the understanding of diagenetic process and their impact on reservoir properties of the Lower Goru sandstone in the Lower Indus Basin and adjoining areas.
\end{abstract}

Keywords Diagenesis $\cdot$ Indus Basin $\cdot$ Lower Goru $\cdot$ Porosity $\cdot$ Reservoir quality $\cdot$ Sandstone

Renhai Pu

purenhai@nwu.edu.cn

Qamar UZ Zaman Dar

darqamar80@yahoo.com

Christopher Baiyegunhi

christopher.baiyegunhi@ul.ac.za

Ghulam Shabeer

shabeer.ghulam1@outlook.com

Rana Imran Ali

ranageologist2003@yahoo.com

Umar Ashraf

umarash2010@hotmail.com

Zulqarnain Sajid

zulqarnainsajid786@gmail.com

Mubashir Mehmood

mubashirmehmood94@gmail.com
1 Department of Geology, Northwest University, Xi' an 710069, People's Republic of China

2 Department of Geology and Mining, Faculty of Science and Agriculture, University of Limpopo, Private Bag X1106, Sovenga 0727, Limpopo, South Africa

3 Goldensun Petroleum Services and Technology, 44000 Islamabad, Pakistan

4 Kuwait Foreign Petroleum Exploration Company (KUFPEC), Islamabad 44000, Pakistan

5 Institute for Ecological Research and Pollution Control of Plateau Lakes, School of Ecology and Environmental Science, Yunnan University, Kunming 650500, China

6 UniversitiTeknologi Petronas: UniversitiTeknologi PETRONAS, Persiaran UTP, Seri Iskandar, 32610 Perak, Malaysia

7 Department of Geology, Abdul Wali Khan University Mardan, Mardan 232000, Pakistan 


\section{Introduction}

The effect of diagenesis and depositional environment on reservoir properties is significant in petroleum exploration (Morad et al. 2010) because it will advocate the economic appraisals Ashraf et al. 2016. The heterogeneity of sedimentary rocks and reservoir quality generally depends upon primary depositional elements and secondary diagenetic alterations (Bjørlykke 2012; Makeen et al. 2016; Ali et al. 2021). Reservoir characteristics of the sandstone such as geometry, mineralogical composition, pore characteristics, porosity, permeability, textural framework, and maturity are evaluated by depositional settings of the sandstones, whereas the diagenesis may affect the reservoir porosity by post-depositional processes (Bjørlykke 2014; Cantarero et al. 2020; Mangi et al. 2020). Reservoir quality is the main factor controlling the prospectivity during the exploration and production of hydrocarbon (Zhang et al. 2020). Lower Goru sandstone reservoirs in the Lower Indus basin have been studied with the help of core cuttings of well KD-01 well from the sandstone intervals. Integrated petrographic studies, scanning electron microscope (SEM) and X-ray diffraction (XRD) investigations, as well as porosity and permeability measurements, have been studied to figure out diagenetic impacts on the reservoir characteristics of oil and gas producing units of the Cretaceous Lower Goru Formation.

The Lower Goru Formation in the Lower Indus Basin and Middle Indus Basin of Pakistan is among the hydrocarbon producing reservoir (Ashraf et al. 2020b; Ali et al. 2020). Over the past few decades, the Lower Goru reservoir has attracted huge attention from researchers because of its hydrocarbon potentiality and depositional settings but vast hydrocarbon potential remained unexplored (Ashraf et al. 2020a; Ali et al. 2020). A productive petroleum system of both the source and reservoir Early Cretaceous Sembar and overlying Lower Goru Formation, respectively, have been used for hydrocarbon production for more than twenty years with good success and production rate (Jamil et al. 2012).

Among different authors work the most significant contribution has been made by (Kadri 1995; Robison et al. 1999; Zaigham and Mallick 2000; Ahmad et al. 2004, 2010; Baig et al., 2016; Yasin et al. 2019; Ashraf, et al. 2019; Ashraf, et al. 2021; Qadri 2019) to study the petroleum prospect stratigraphy and regional tectonic setting of the basin. To date, there are only a few research studies on the diagenetic impacts controlling reservoir characters of the sandstones. The most significant work has been done by Berger et al. 2009 on the C sand of the Lower Goru Formation in which they investigated that presence of chlorite coats is the substantial mechanism for preserving porosity.
Baig et al. (2016) investigated the Basal and Massive sand of the Lower Goru Formation and assess the diagenetic control on the reservoir properties of the sandstone they concluded that existence of abundant chlorite coats and low quartz cement are the main diagenetic reasons for the occurrence of high porosity in the massive and basal sands. This study examines that the same process operates in the reservoir encountered in the KD-01 area.

Hence, a gap still exists between the reservoir characteristics and associated impacts on reservoir quality of the other sand units of the Lower Goru Formation because of the diagenesis of the Early Cretaceous Lower Goru sandstone reservoir in the area. This research was carried out to undertake a comprehensive diagenetic analysis of the reservoir, to figure out the diagenetic history and effects on reservoir properties, to investigate how the composition and depositional environment has an effect on the reservoir characters of the sandstone. This study will improve understanding of the pore types, cement types, diagenetic sequence, and diagenetic impacts on the reservoir characters.

\section{Geological setting}

The present study is on the Lower Goru sandstone from the central part of the Lower Indus Basin of Pakistan (Fig. 1). The formation is located in an area where Sargodha high is present in the northern side, Sulaiman fold and thrust belt is situated in the western side, Indian shield is located in the eastern side, and toward the south Jacobadad-Khairpur high is present (Kadri 1995; Afzal et al. 2009; Naeem et al. 2016; Berger et al. 2009; Azeem et al. 2013). Sedimentary rock units in the region consist of Triassic (Wulgai Formation) to Quaternary alluvium (Berger et al. 2009; Fig. 2). Lower Goru Formation of the Early Cretaceous consists of some sand units which are showing good characters of a reservoir, upper portion of the formation is comprised of siltstone, sandstone along with shale, in the basal portion some intercalated limestone and shale are present within the sandstone (Kadri 1995). The Lower Goru Formation is divided into different units named as A, B, C, and D sand units (Mahmoud 2015) (Fig. 2). The sandstone unit present within the formation is suggested to be deposited during sea-level low stand within a shallow marine environment, however, coarse grain deposits were formed on top of the distal sediments of the prior high stand system tract (Berger et al. 2009; Ashraf et al. 2021). Indian Shield rocks to the eastern side are the source of the Lower Goru Formation, these Shield rocks consist of the Precambrian granites and metamorphic rocks. The sandstone units showing reservoir characters are a product of different depositional environments, ranging from deltaic, fluvial, barrier bars, shallow marine, and shoreface to offshore depositional environment 


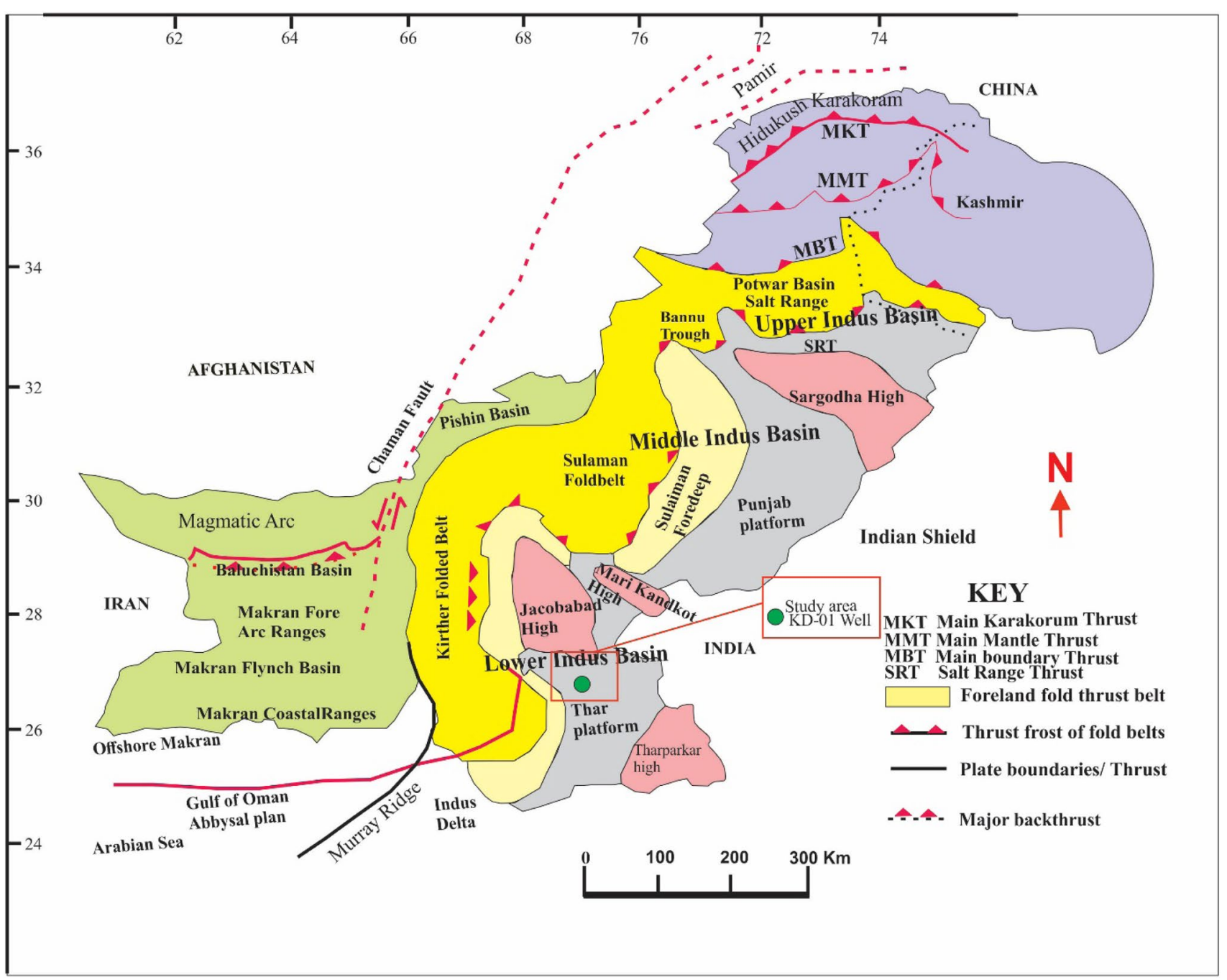

Fig. 1 Geological map of Pakistan showing the location of the Lower Indus Basin inset showing the location of well KD-01 (modified after (Kadri 1995)

(Kadri 1995; Krois et al. 1998; Ashraf et al. 2021). The extensively distributed Cretaceous Sembar Formation acts as source rock in the area (Khalid et al. 2014; Yasin et al. 2017). The stratigraphic section of exploration well KD-01 is shown in (Fig. 3).

\section{Material and methods}

A total of 50 samples from the sandstone reservoir intervals from the Lower Goru Formation were used from exploration well KD-01 and analyzed for petrographic microscopy, $\mathrm{X}$-ray diffraction (XRD), and scanning electron microscopy (SEM). Thin sections petrographic analysis have been done for the purpose of determination of the mineralogical composition, cement types and textural framework, and porosity.
The selected core samples of the sandstone were used for porosity recognition, these samples were soaked with blue epoxy to enhance the visibility of carbonate minerals. A total of 300 point counts were used in each thin section to study the modal composition of the sandstone, with the method suggested by (Dickinson et al. 1979; Dickinson et al. 1983). The framework grains of the sandstone of the Lower Goru Formation have been divided into quartz monocrystalline and polycrystalline, feldspar, rock fragments, mica, cement (authigenic clay, carbonate, and silica), and matrix. During thin section point counting study the numbers of pore spaces were also counted. Petrographic analysis and visual porosity were found out through Olympus Bx50 petrographic microscope set with digital camera.

Thin section point count data were also used for intergranular volume IGV estimation. The framework grains of the Lower Goru Sandstone were characterized into quartz, 


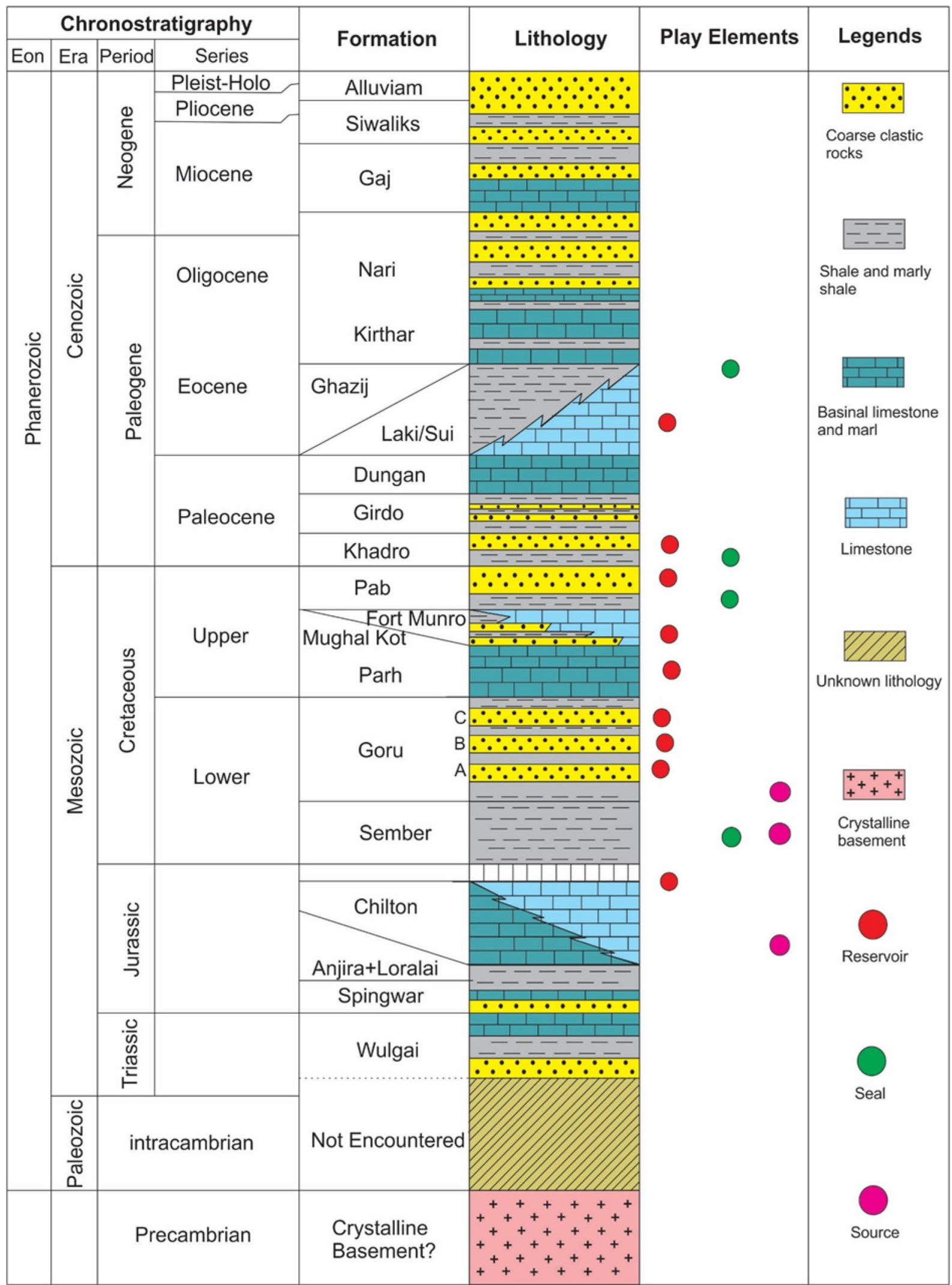

Fig. 2 Generalized stratigraphy of the study area (modified after (Qureshi, Ghazi et al. 2021) 
Fig. 3 Stratigraphic section of the KD-01 Well (modified after (Qureshi, Ghazi et al. 2021)

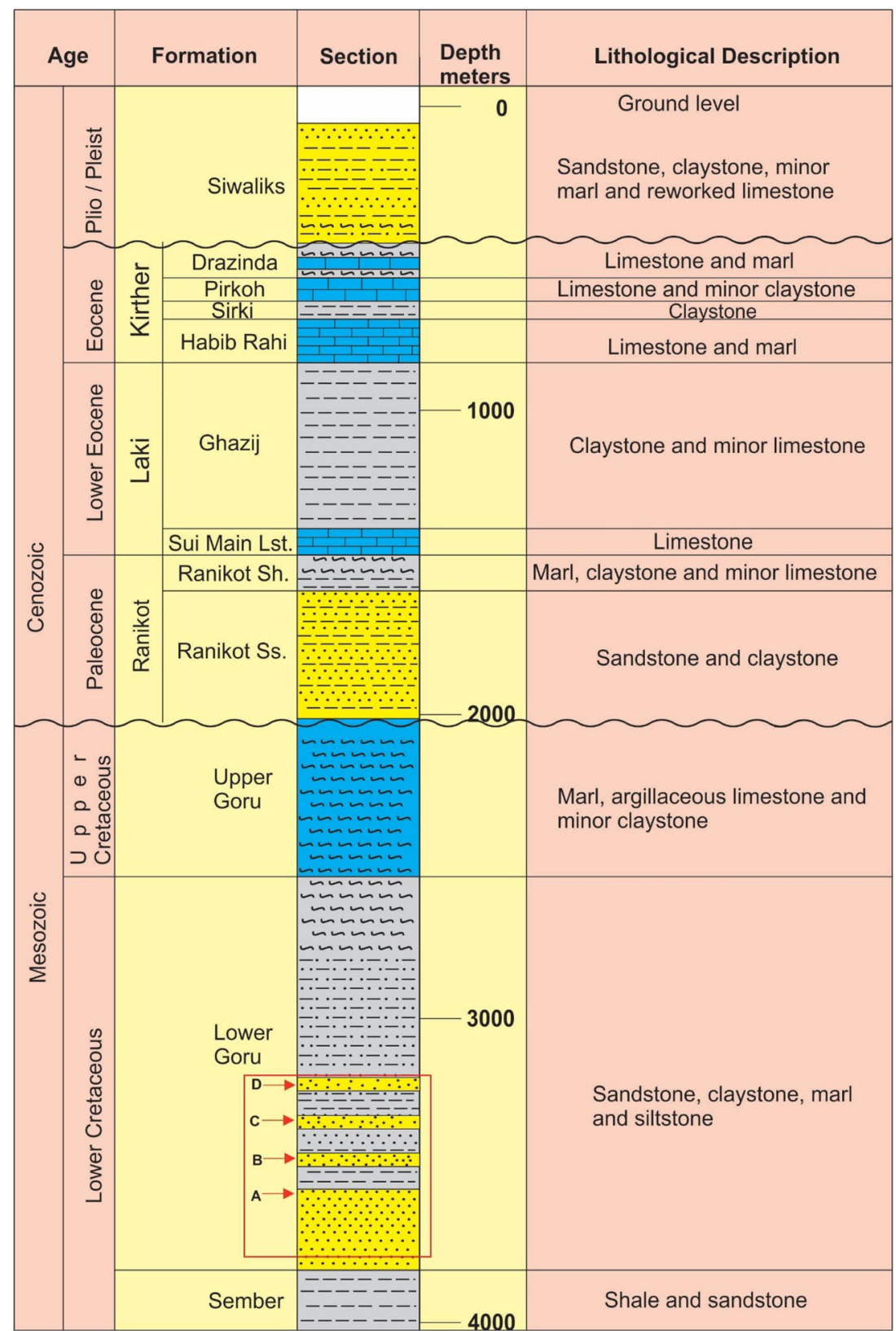

feldspar, lithic fragments, organic fragments, glauconite, mica, and matrix. To confirm the mineralogical composition using petrographic studies, ten representative sandstone samples were analyzed by XRD. Information about the clay mineral presence in the reservoir has been derived through the XRD analysis. Back-loading method was used for the XRD analysis.

Furthermore, authigenic minerals, diagenetic texture, quartz overgrowth, and dissolution effect were analyzed using SEM. For SEM, the samples were cleaned, gold coated, and analyzed by using a scanning electron microscope. The prepared samples were investigated in backscattered electron and secondary electron imaging modes. The porosity and permeability results were derived through petrographic and SEM analysis. The minerals distribution and pore morphology was observed by using FEI quanta 400 FEG SEM. The Hydrocarbon Development Institute of Pakistan (HDIP) provided the helium porosity and permeability information of the sandstone samples from the KD-01 well. 


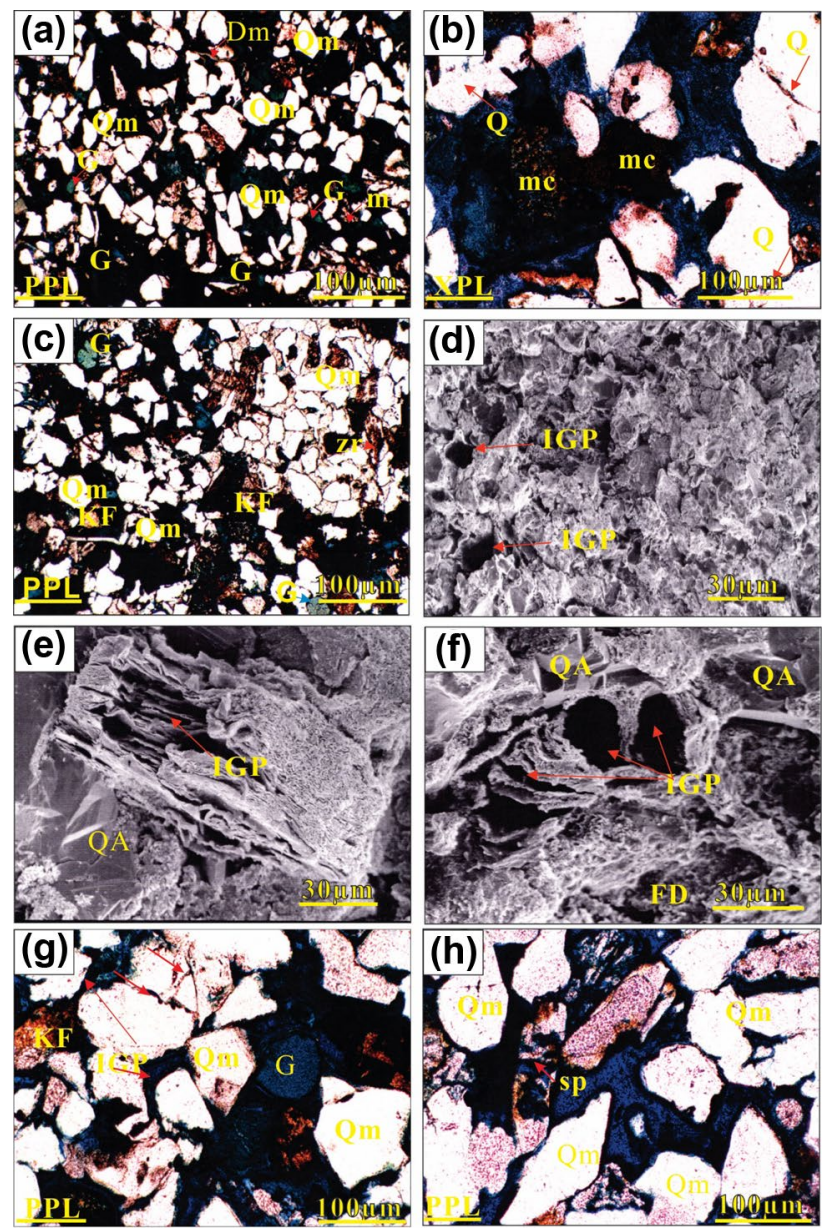

Fig. 4 Photomicrographs and SEM images a Well KD-01, $3142 \mathrm{~m}$, Glauconite $(\mathrm{G})$, deformed mica $(\mathrm{dm})$, monocrystalline quartz $(\mathrm{Qm}), \mathbf{b}$ Well KD-01, $3142 \mathrm{~m}$, XPL view clay coatings on quartz grains mc is mud clasts red arrows show the quartz overgrowth $\mathbf{c}$ Well KD-01, $3145 \mathrm{~m}$, framework grains of sandstone, glaconite $(\mathrm{G})$, monocrystalline quartz (Qm), potassium feldspar (Kf), zircon (zr) d Well KD-01, $3150 \mathrm{~m}$, intergranular porosity e Well KD-01, $3150 \mathrm{~m}$, intergranular porosity within deformed mica authigenic quartz (QA), f Well KD-01, $3151 \mathrm{~m}$, intergranular porosity within feldspar grains, authigenic feldspar (QA), intergranular porosity (IGP), feldspar dissolution (FD) g Well KD-01, $3155 \mathrm{~m}$, glauconite (G), potassium feldspar (Kf), and red arrows show quartz overgrowth(h)Well KD-01, $3155 \mathrm{~m}$, intergranular pores within leached feldspar (sp)

\section{Results and discussions}

\section{Petrography and modal composition}

Petrographic investigations reveal that the sandstone is composed of detrital constituents, accessory minerals, cement, matrix, and pores (Fig. 4, Table 1). The detrital constituents include quartz, feldspar, glauconite, and lithic fragments with some minor amount of mica, zircon, and rutile. The Lower Goru reservoir sandstone is mainly medium to coarse grained (Table 1). The major detrital mineral found out in the studied sample is Quartz. Monocrystalline detrital quartz is dominant and polycrystalline quartz is less abundant. Mineralogically the Lower Goru reservoir sandstone is predominantly consisting of quartz, feldspar, and rock fragments. The overall framework of the grains consists of 40 to 50 percent of monocrystalline quartz grains, these grains are subangular to rounded. Polycrystalline quartz is less common with an average of $1.2 \%$. The dominant monocrystalline quartz suggests derivation from plutonic rocks Folk 1974. Medium to coarse grained polycrystalline quartz was identified which shows the information about the metamorphic sources. The second most abundant detrital component identified in the sandstone was feldspar which is about 14 to 20 percent of the total framework. The feldspar grains are subangular to subrounded in shape. K-feldspar is the dominant type of feldspar while plagioclase is less common. The feldspar grains display partial to wide range leaching. SEM analysis and petrographic analysis show that feldspar is highly altered and fractured feldspar. The lithic grains constitute about 4 to $7 \%$ of the framework grains and are dominantly comprised of mud clasts, grains of igneous material, chert, and foraminiferal debris (Table 1). The organic fragments were observed in all the samples of the sandstone ranging from 1 to $4 \%$. The fragments became compacted during compaction and lie parallel to bedding.

Rounded green color grains of glauconite (Fig. 4a) are there in almost all the investigated sandstone of the Lower Goru Formation (Table 1). The glauconite is present in the form of tiny grains, cement, and pellets in the sandstone. The glauconite range from 0.5 to $3 \%$ with an average of $2.1 \%$ of the total framework. The glauconite grains are rounded to subrounded and elliptical in shape. The glauconites display light green color under plane-polarized light and exhibit green to dark green color under the crosspolarized light (Fig. 4b). Among the framework grains the matrix and cement act as cementing materials. About 1 to 2 percent of the framework composition is consists of matrix and are mostly clay minerals of detrital nature or formed diagenetically. Zircon and sphene grains are also observed in the Lower Goru Formation (Fig. 4c.) Trace amounts of biotite and muscovite are existing in all the analyzed samples (Fig. 4c). Grains of biotite and muscovite are deformed or turned due to compaction.

\section{Sandstone classification}

Based on the total quartz, feldspar, and lithic fragments (Q-F-L) plot of the framework grain composition (Table1) on the background diagram of (Folk et al. 1970), the sandstones studied from the Lower Goru Formation are classified as arkose and feldspathic arenite (Fig. 5). According to (Pettijohn et al. 1987), the rock will be considered as arenite 


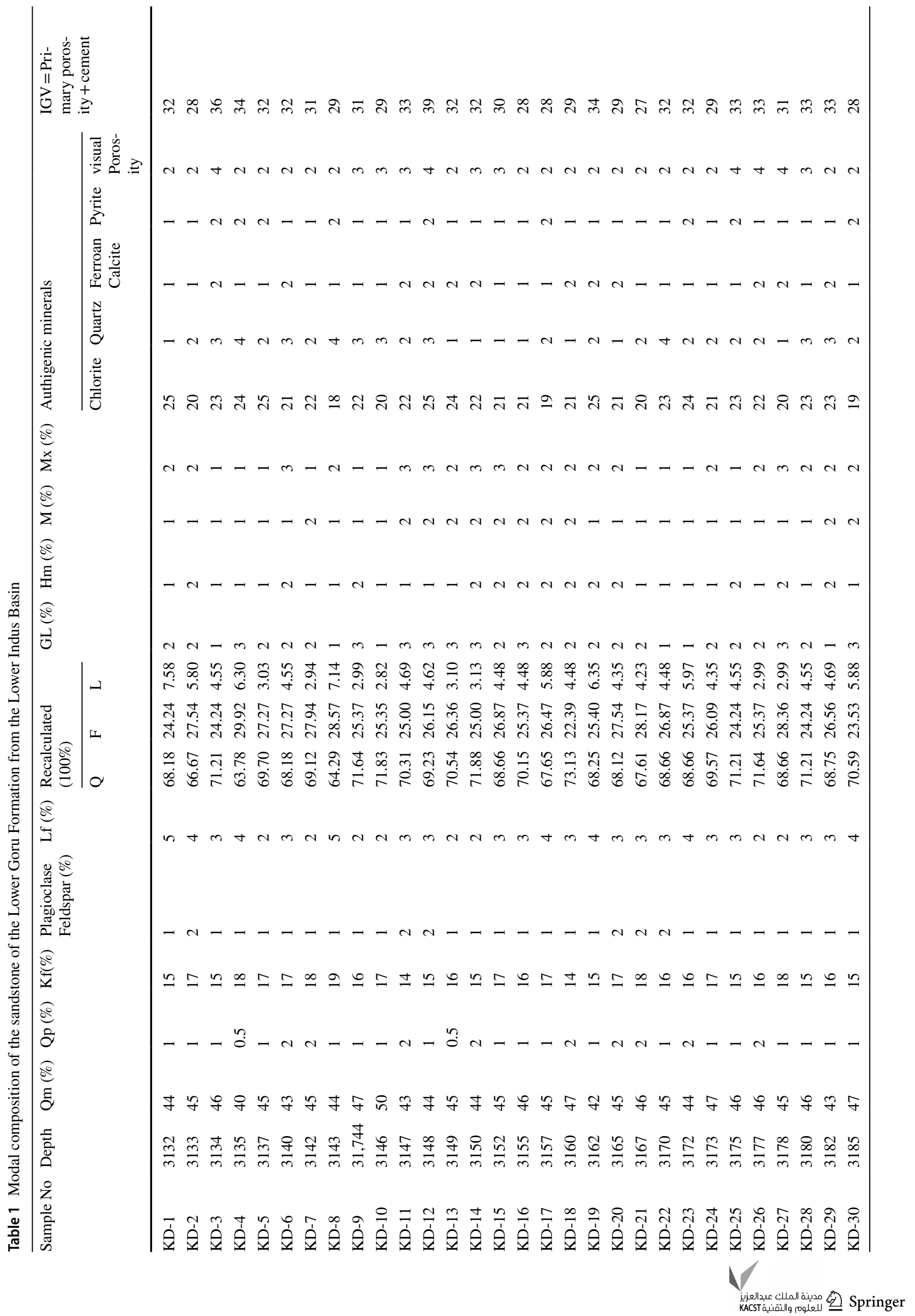




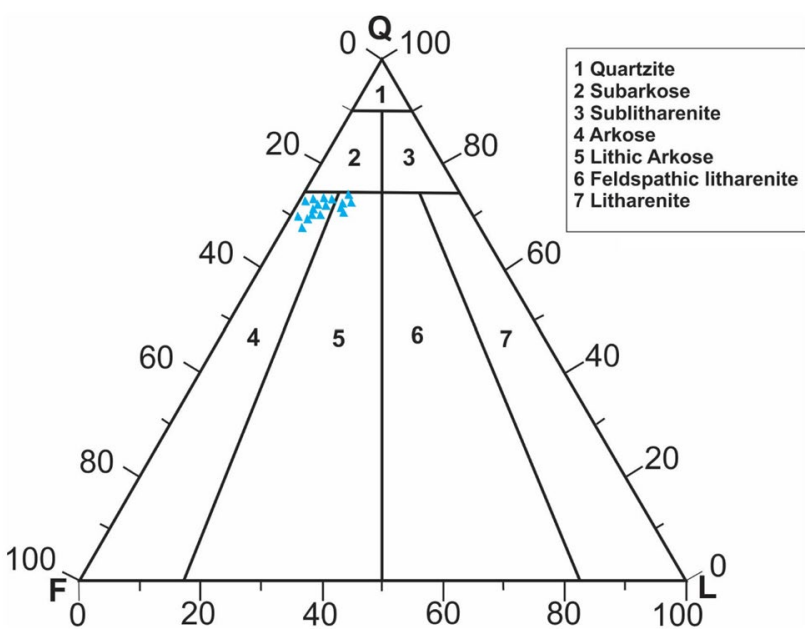

Fig. 5 Sandstone modal data plot of the total quartz-feldspar-lithic fragments (Q-F-L) on the background ternary diagram of Folk (1974)

if the total matrix is less than $15 \%$, and it will be considered as wacke if the percent of matrix is inbetween 15 and $75 \%$. Based on the percentages of the matrix presented in (Table 1), the sandstones can be classified as arenites. The classification system used in this study is based on the QFL ternary diagram of (Folk 1974) and (Dickinson et al. 1983).

\section{Reservoir properties}

\section{Porosity and permeability}

The helium porosity of the investigated core samples ranges from 7.2 to $20 \%$ with an average of $12.4 \%$ (Table 3). Horizontal permeability concentrates from 0.04 to $0.24 \mathrm{mD}$ with an average of $0.23 \mathrm{mD}$. Porosities were also assessed by the petrographic point count analysis. Porosity estimated by thin section analysis of the sandstone range from 2 to $4 \%$, averaging $2.53 \%$. In the analyzed sandstone samples, three pore types were identified by petrographic and SEM analysis. The pore types are primary intergranular pores (Fig. 4d), intercrystalline pores, and solution pores (Fig. $4 \mathrm{e}-\mathrm{f}$ ) are the three main pore types identified by petrographic and SEM analysis. The intergranular pores volumes are estimated to range from 27 to $39 \%$ and are reduced by mechanical compaction, chlorite cementation, and to a minor extent by quartz, pyrite, and ferroan calcite cementation. The solution pores are caused by feldspar dissolution (Fig. $4 \mathrm{~g}-\mathrm{h}$ ).

\section{Mineralogy by X-ray diffraction analysis}

The XRD analysis of the Lower Goru sandstone reveals that the most abundant mineral is quartz ranging from 50 to $55 \%$ (Table 2). The feldspar is the second-highest mineral found in the sandstone composition ranging from 11 to $20 \%$, while the highest clay mineral is chlorite with a composition ranging from 10 to $30 \%$. Chlorite and mixed concentrations of illite and smectite are identified as common clay minerals. Carbonate minerals like calcite, dolomite, are also present diffractogram are given in (Fig. 6).

\section{Diagenesis of the Lower Goru sandstones}

The Lower Goru sandstone has experienced complex diagenesis, which has severely influenced the mineralogy and reservoir characters. Cementation, compaction, and pressure solution are considered as the principal diagenetic events (Table 3).

\section{Cementation}

Cementation is a significant process of formation of consolidated rock from loose sediments and causes a reduction in

Table 2 Whole rock mineralogy determined by XRD

\begin{tabular}{|c|c|c|c|c|c|c|c|c|c|}
\hline Sample ID & $\begin{array}{l}\text { Quartz } \\
\%\end{array}$ & $\begin{array}{l}\text { K-Feldspar } \\
\%\end{array}$ & $\begin{array}{l}\text { Plagioclase } \\
\%\end{array}$ & $\begin{array}{l}\text { Chlorite } \\
\%\end{array}$ & $\begin{array}{l}\text { Dolomite } \\
\%\end{array}$ & $\begin{array}{l}\text { Anhydride } \\
\%\end{array}$ & $\begin{array}{l}\text { Pyrite } \\
\%\end{array}$ & $\begin{array}{l}\text { Mixed lay- } \\
\text { ers I/S } \\
\%\end{array}$ & $\begin{array}{l}\text { Calcite } \\
\%\end{array}$ \\
\hline KD-1 & 50 & 10 & 3 & 30 & 0.5 & 1 & 0.5 & 4 & 1 \\
\hline $\mathrm{Kd}-2$ & 54 & 16 & 4 & 14 & 2 & 2 & 1 & 3 & 4 \\
\hline KD-3 & 54 & 12 & 9 & 16 & 1 & 2 & 1 & 3 & 2 \\
\hline KD-4 & 50 & 15 & 8 & 17 & 1 & 2 & 1 & 4 & 2 \\
\hline KD-5 & 53 & 11 & 10 & 18 & 1 & 1 & 2 & 3 & 1 \\
\hline KD-6 & 50 & 10 & 7 & 23 & 2 & 1 & 2 & 2 & 3 \\
\hline KD-7 & 51 & 12 & 9 & 20 & 1 & 2 & 1 & 2 & 2 \\
\hline KD-8 & 54 & 11 & 4 & 23 & 1 & 1 & 2 & 2 & 2 \\
\hline KD-9 & 50 & 10 & 8 & 21 & 2 & 1 & 1 & 3 & 4 \\
\hline KD-10 & 53 & 8 & 7 & 22 & 1 & 2 & 1 & 4 & 2 \\
\hline
\end{tabular}



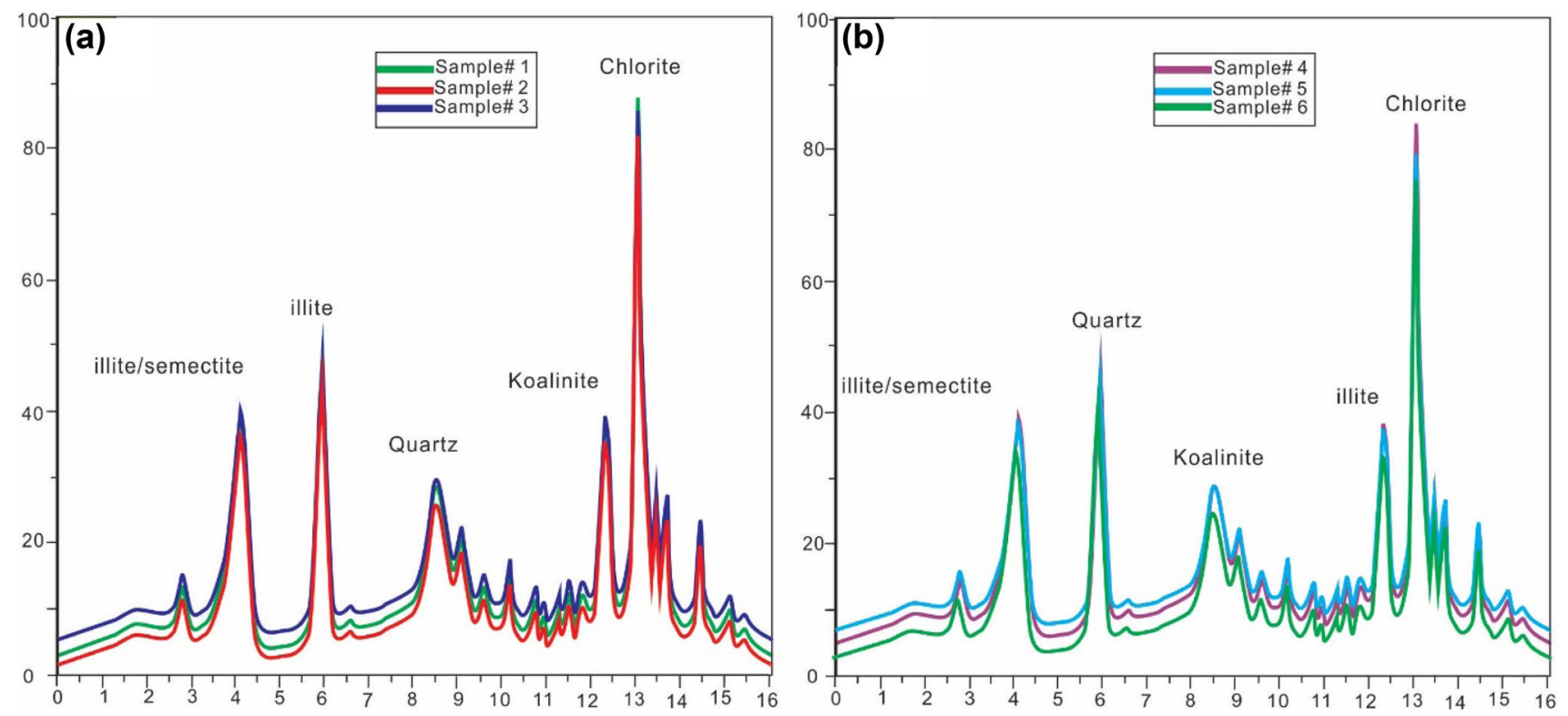

Fig. 6 X-ray diffractograms of the investigated showing the presence of the Chlorite, illite and Koalinite

Table 3 Helium porosity and permeability of the core samples from KD-01 Well

\begin{tabular}{llllll}
\hline Sample ID & $\begin{array}{l}\text { Depth } \\
(\mathrm{m})\end{array}$ & $\begin{array}{l}\text { Helium porosity } \\
(\%)\end{array}$ & $\begin{array}{l}\text { Permeability } \\
\text { horizontal } \\
(\mathrm{mD})\end{array}$ & $\begin{array}{l}\text { Permeability } \\
\text { vertical } \\
(\mathrm{mD})\end{array}$ & $\begin{array}{l}\text { Grain density } \\
\left(\mathrm{g} / \mathrm{cm}^{3}\right)\end{array}$ \\
\hline 1 & 3141 & 20.3 & 0.23 & 0.15 & 2.66 \\
2 & 3142 & 18.2 & 0.22 & 0.12 & 2.71 \\
3 & 3145 & 15.8 & 0.33 & 0.11 & 2.7 \\
4 & 3146 & 17.1 & 0.24 & 0.16 & 2.65 \\
5 & 3147 & 16.8 & 1.09 & 0.01 & 2.71 \\
6 & 3150 & 4.2 & 0.59 & 0.04 & 2.72 \\
7 & 3152 & 11.3 & 0.21 & 0.03 & 2.7 \\
8 & 3155 & 13.9 & 0.06 & 0.03 & 2.7 \\
9 & 3156 & 12.4 & 0.02 & 0.01 & 2.71 \\
10 & 3157 & 8.5 & 0.03 & 0.04 & 2.73 \\
11 & 3160 & 9.8 & 0.03 & 0.04 & 2.72 \\
12 & 3165 & 10.6 & 0.04 & 0.21 & 2.71 \\
13 & 3167 & 7.2 & 0.11 & 0.02 & 2.72 \\
14 & 3170 & 10.11 & 0.22 & 0.10 & 2.73 \\
15 & 3175 & 11 & 0.04 & 0.12 & 2.72 \\
\hline
\end{tabular}

porosity. Quartz, ferroan calcite, pyrite, and clay minerals cementation are the four major types of cement in the lower Goru sandstone as identified by SEM, thin section studies, and XRD analysis.

\section{Quartz cementation}

In the Lower Goru sandstone, quartz cement acts a quartz overgrowth and pore filling (Fig. 7a-b). The investigated samples show quartz overgrowth on the grains of detrital quartz. SEM analysis of the investigated sandstone shows that authigenic quartz formed in the pore spaces by replacing the clay matrix (Fig. $4 \mathrm{e}-\mathrm{f}, 9 \mathrm{c}-\mathrm{e}$ ). The distribution of authigenic quartz in the studied sandstone is chiefly controlled by chlorite cementation. The source of quartz cement in the sandstone has been questioned for a long time concerning internal silica source or external source (Gier et al. 2008; Islam 2009; Xi et al. 2015). The solubility of $\mathrm{SiO}_{2}$ is low in the closed system with controls of water and significant incongruity in permeability 

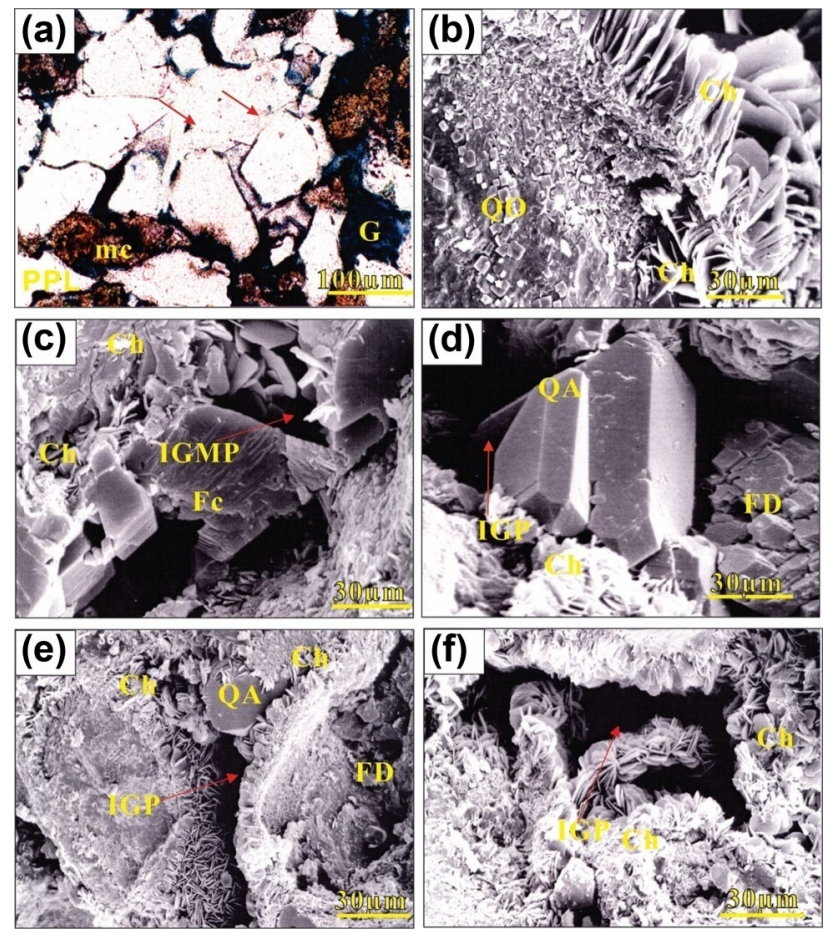

Fig. 7 a Well KD-01, $3160 \mathrm{~m}$, red arrows shows quartz overgrowth b Well KD-01, $3162 \mathrm{~m}$, General overview intergranular porosity c Well KD-01, 3165 m, Ferroan calcite (FC) occluding intergranular porosity, intergranular micro porosity (IGMP) within chlorite cement d intergranular pore lined with chlorite, authigenic quartz (QA), feldspar dissolution (QA), chlorite cement (Ch). e Well KD-01, 3166 m, intergranular pore partially blocked by grain rimming chlorite, authigenic quartz $(\mathrm{Ch})$, dissolution feldspar (FD), intergranular porosity (IGP) f Well KD-01, $3168 \mathrm{~m}$, chlorite cement occluding intergranular pore and blocking pore throats, intergranular porosity (IGP), chlorite cement $(\mathrm{Ch})$

and porosity, the advective flow, diffusion, or thermal convection could elucidate long distance and enormous transmission of external $\mathrm{SiO}_{2}$ into sandstones (Bjørlykke et al. 1988; Bjørlykke 2011; Bjørlykke and Jahren 2012). Hence, the possible internal origin of silica in the sandstone is feldspar dissolution, clay mineral diagenesis, and volcanic rock fragments (Bjørlykke and Egeberg 1993; Hyodo et al. 2014; Sajid et al.2020).

\section{Calcite cement}

Calcite is another type of cement recognized in the Lower Goru sandstone (Fig. 7c) which mainly occurs as pore filling or replacement mineral of detrital grains or clay matrix. It occurs as a minor poikilotopic cement that may infill intergranular porosity. In few samples, it replaces
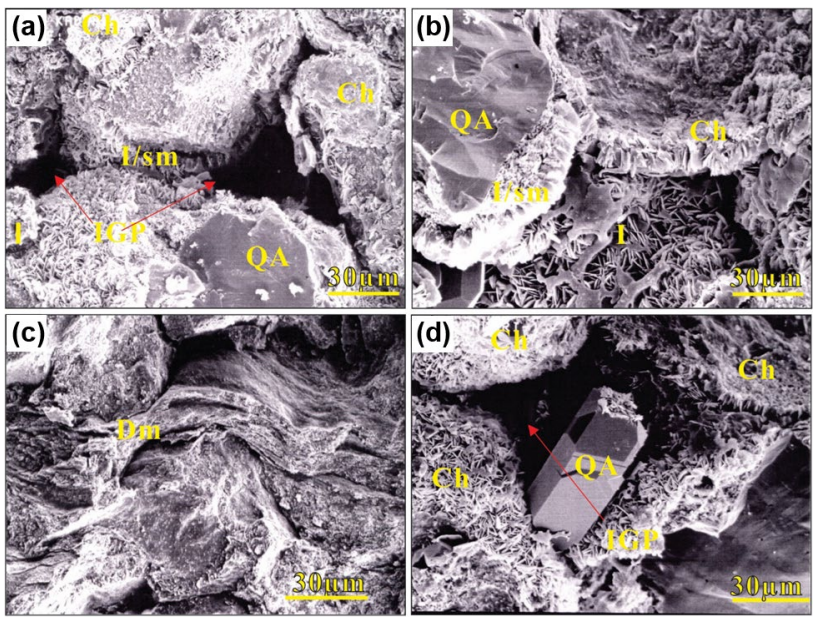

Fig. 8 SEM images of the a Well KD-01, $3170 \mathrm{~m}$, pore throat are seriously affected by chlorite lining, chlorite cement and a layer of illite/smectite b Well KD-01, $3172 \mathrm{~m}$, grain rimming chlorite cement, authigenic quartz and sheet like mixed layer illite/illite-smectite which postdate the chlorite, authigenic quartz (QA) c Well KD-01, $3175 \mathrm{~m}$, compaction texture possibly deformed mica d Well KD-01, $3176 \mathrm{~m}$, intergranular pore lined by chlorite cement which rigorously restricts pore throat diameter, intergranular porosity (IGP), chlorite cement (Ch), authigenic quartz (QA)

detrital grains. In few samples, the calcite shows evidence of partial dissolution.

\section{Clay minerals cementation}

\section{Chlorite cementation}

This is the most significant authigenic phase preceding both quartz overgrowth and feldspar dissolution. SEM analysis shows that the chlorite has euhedral shapes and is organized in a rose pattern (Fig. $7 d-f$ ). The dissemination of authigenic quartz is generally controlled by the range of chlorite cementation. Persistent chlorite cementation confines existing space for quartz precipitation. This cement could partly or entirely block the intergranular porosity and generally confines the diameter of pore throats (Fig. 7d-e). Chlorite occurs as grain rimming cement and is considered responsible for preserving the porosity in various deep reservoirs sandstones seemingly by inhibiting quartz overgrowth cementation and pressure dissolution (Pittman and Larese 1991; Berger al. 2009; Chen et al. 2011; Bahlis and De Ros 2013).

\section{Illite and smectite cementation}

A minor amount of sheet-like structures was observed by SEM analysis most probably sheet-like mixed layers of illite and illite-smectite (Fig. 8a-b). Mixed-layer illite-smectite 
occurs a pore-filling cement or pore-lining grain coating cement was observed in SEM images in the analyzed samples. Mixed-layer illite-smectite is formed by the compaction of mud intraclasts or transformation of detrital smectite convert to mixed-layer illite-smectite with increasing burial depth.

\section{Compaction}

Mechanical compaction of the Lower Goru reservoir sandstone has been initiated after deposition. In this stage deformation of less competent mineral occur. Compaction resulted in deformation of micas, organic fragments, and mud clasts (Fig. 7c). Chemical compaction or pressure dissolution was identified between the framework grains by the presence of curved to convex contacts among the framework grains. The thin section studies reveal that the early stage chlorite cementation disallowed significant compaction of the sediments.

\section{Dissolution}

Generation of secondary pores and development of porosity occurred because of the dissolution of less competent grains generates the secondary pores and increases the porosity of a reservoir sandstone (Yu et al. 2019). SEM analysis of the Lower Goru sandstones reveals a huge amount of less competent mineral altered because of dissolution. Dissolution in the feldspar grains caused intergranular porosity in the sandstone. The secondary pores suggest that the carbonate cement and feldspar dissolution generated the secondary porosity (Fig. 7c-d). Various feldspar grains display strong diagenetic alterations and dissolution and replacement by calcite or kaolinite.

\section{Mineral replacement}

The mineral replacement process includes the dissolution of one mineral and instantaneous precipitation of a different mineral (Baiyegunhi et al. 2017). The potassium feldspar is most affected, and the plagioclase is less affected in the lower Goru sandstone. The replacement of feldspar by albite or calcite caused the formation of new pores in the sandstone (Fig. 7c). SEM observations reveal that K-feldspar grains are also generally transformed to sericite and kaolinite. Albite precipitation occurred favorably in the microfractures, grains contact margins, and cleavages of the sandstone.

\section{Diagenetic sequences}

Based on the identified textures and structures of diagenesis in the rock are grouped into early diagenesis, burial diagenesis, and late diagenesis. The diagenetic regime defined by (Worden and Burley 2003) was used in this study to classify the diagenetic events. Based on the identified textures and structures the Lower Goru sandstone reservoir diagenesis in the rock are grouped into three categories (Fig. 9). Original mineralogy, geochemistry of pore water, and existence of other hydrocarbon-related fluids are affected in early diagenesis. In the Lower Goru sandstone, the early diagenesis processes include chlorite cementation, illite- smectite/smectite cementation, grain leaching, quartz cementation (Dar et al. 2021). The precipitation of pyrite occurs in the late phase of diagenesis glocunite alteration occurs due to reducing
Fig. 9 The paragenetic sequence of reservoir sandstone of the Lower Goru Formation

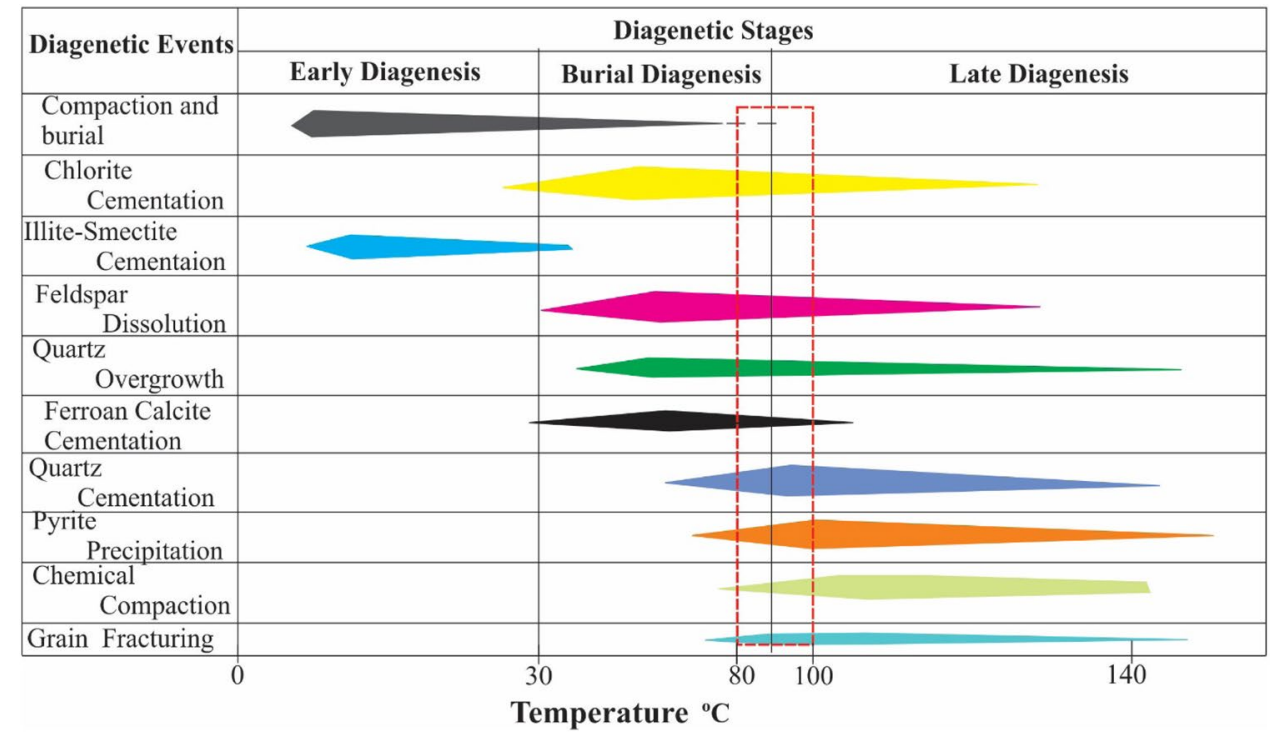




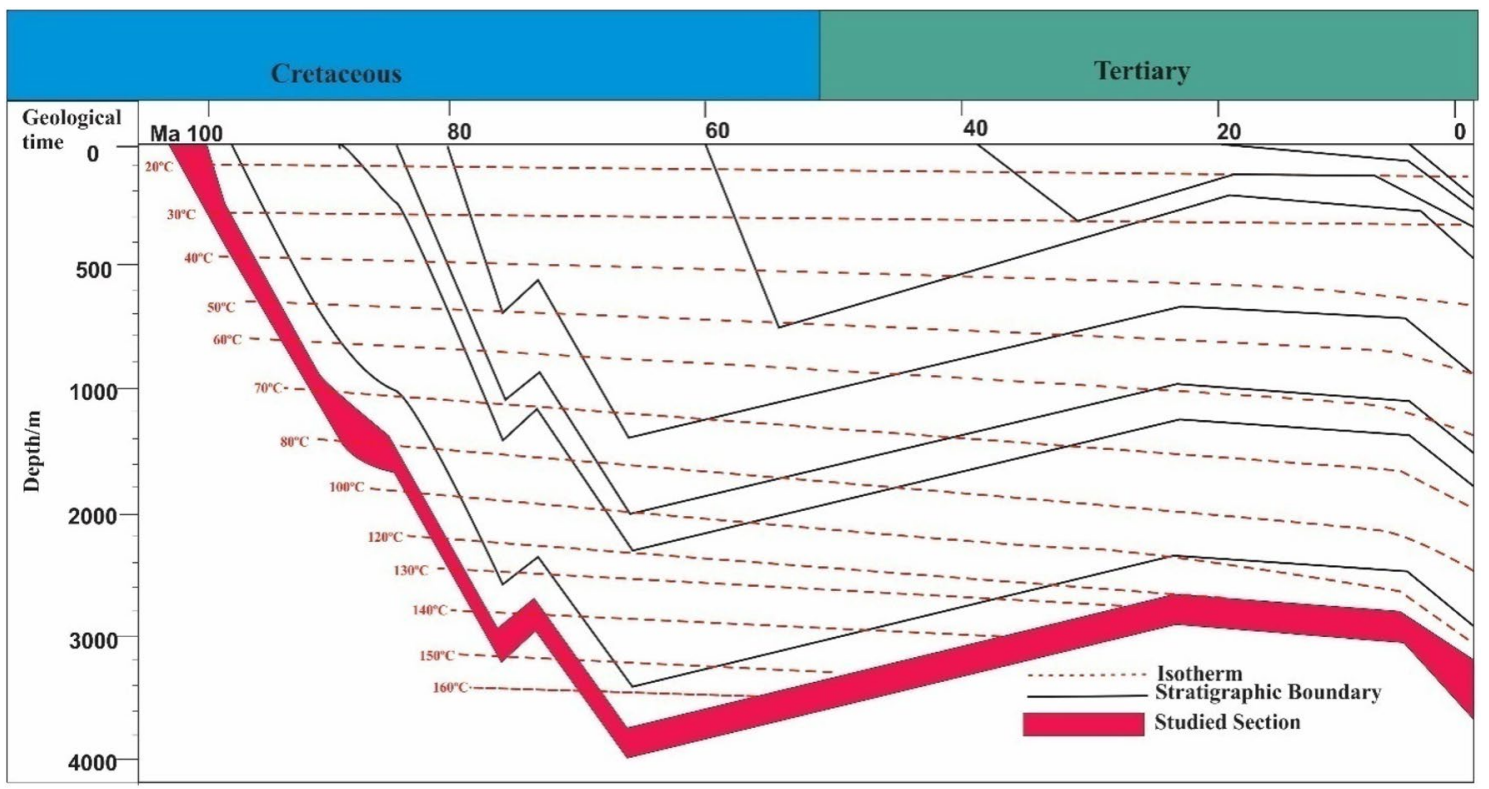

Fig. 10 Burial and thermal history diagram of the Lower Indus Basin

conditions just after burial. The burial history diagram along with geothermal gradient is given in (Fig. 10).

\section{Early diagenesis}

Early diagenesis is the process that occurs when the sediments are near to the surface and in close contact with oxygenated surface-supplied water. The mineralogical composition, grain fabrics, geochemistry of the pore water enclosed in the pores, and temperature history are the key elements that influence early diagenesis (Worden and Morad 2003). The process involves in the early diagenesis includes chlorite cementation, pyrite precipitation, illite- smectite/ smectite cementation, grain leaching, quartz cementation. The iron-rich chlorite was probably precipitated as a poreblocking intergranular cement. The mixed-layer sheet like layers of illite/illite-smectite followed by chlorite cementation. Quartz overgrowth overlies and postdates the chlorite cement. The dissolved silica was most probably derived from feldspar dissolution and disintegration of detrital ferromagnesium minerals. These diagenesis processes destroy the primary and depositional porosity of the reservoir. The chlorite cementation and compaction remain in the early and late stage of diagenesis.

\section{Burial diagenesis}

Burial diagenesis contains physical, chemical, and biological processes that act on the sediments during deposition and continue until the beginning of metamorphism or an uplifting event take place and exposure to meteoric water
(Schmidt and Macdonald 1979; Baiyegunhi et al. 2017). Burial diagenesis is responsible for all the modifications resulting in the sandstone (Baiyegunhi et al. 2017). With the increasing overburden associated with the mechanical compaction burial diagenesis starts. Burial diagenesis all the modifications occurred to the sandstone after consolidation and before metamorphism (Worden and Morad 2003). An increase in temperature and pressure occurs because of the increasing overburden, this event causes partial dissolution of the less competent minerals and results in the recrystallization of some minerals. From the Petrographic study dissolution of feldspar is also identified in the Lower Goru sandstone. The minerals precipitated by feldspar dissolution are usually grain having clay coating such as smectite and illite, pore filling clays such as kaolinite and chlorite and minor calcite cement (Schmidt and Macdonald 1979). The chemical compaction and pressure dissolution of carbonate cement start during burial diagenesis.

\section{Late diagenesis}

The main elements that affect late diagenesis are pressure, increased temperature, and variations in the composition of pore water (Boggs 2009). The above factors cause physical, mineralogical, and chemical changes to develop the equilibrium of sediments with diagenetic environments. The processes include in late diagenesis of the Lower Goru reservoir sandstone were sediment compaction, calcite cementation, and pyrite precipitation (Fig. 9). The petrographic investigation reveals that ferroan calcite was precipitated inside the intergranular pores and substituting the detrital grains. 
Partial dissolution of ferroan calcite cement consequently occurred (Fig. 7c). During the late diagenesis, soft grains like mud clast and organic fragments were compressed and micas were distorted. Clay minerals authigenesis causes the transformation of clay minerals like smectite alteration to illite while chlorite recrystallized into illite (Fig. 8a-b).

\section{Diagenetic controls on reservoir quality}

Reservoir quality, discussed in this study is porosity and permeability which is a function of depositional control on grain size, provenance and diagenetic controls of compaction and burial, cementation of authigenic clay minerals, and dissolution (Islam 2009; Xi et al. 2015).

The grains packing of investigated sandstone samples shows mechanical compaction as well as chemical compaction. Based on petrological studies and helium porosities measurements the sandstone has a good porosity value. The relationship between burial compaction and ductile grain can be investigated by (IGV) intergranular volume. The IGV indicates the maximum porosity of sandstone that can be predicted (IGV = intergranular porosity + pore-filling cement (Chiang and Ding 2013). The compaction of the sandstone was measured by intergranular volume IGV which is a good index of the compaction of the reservoir sandstone. The IGV value ranges from 27 to 39\% (Table 1) an IGV value of more than $26 \%$ in a well-sorted sandstone shows porosity reduction by compaction (Paxton et al. 2002).

The binary plot of the intergranular volume values (IGV) versus the volume of the pores (Houseknecht drawings) shows that the porosity destruction in the Lower Goru sandstone reservoir is dominated by compaction than cementation (Fig. 11). A plot of IGV versus cement volume directs that mechanical compaction has played a more significant role than cementation in reducing the primary porosity of the Lower Goru sandstone reservoir. Cementation has also played a role in decreasing porosity and permeability of the Lower Goru sandstone reservoir, however, the mechanical compaction is volumetrically the more significant.

The most abundant authigenic cement types occluding the pores are quartz, ferroan calcite, and clay minerals. At the same time, this sandstone retains excellent porosity because it has survived during the compaction processes. However, they do not have a good permeability value. Most of the primary porosity of the Lower Goru sandstone was destroyed by the authigenic clay minerals cementation or occasionally by the replacement of feldspar (Fig. 7c, e). During diagenesis, intergranular porosity is reduced by cementation and slightly enhanced by the dissolution of minerals, and pores produced by dissolution are filled by cement where porosity is generated (Fig. $7 \mathrm{c}-\mathrm{d}$ ). Also, the porosity of the Lower Goru sandstone has been reduced by early chlorite
Fig. 11 Intergranular volume IGV plot against volume of cement in the Lower Goru sandstone reservoir (modified from Houseknecht 1988)

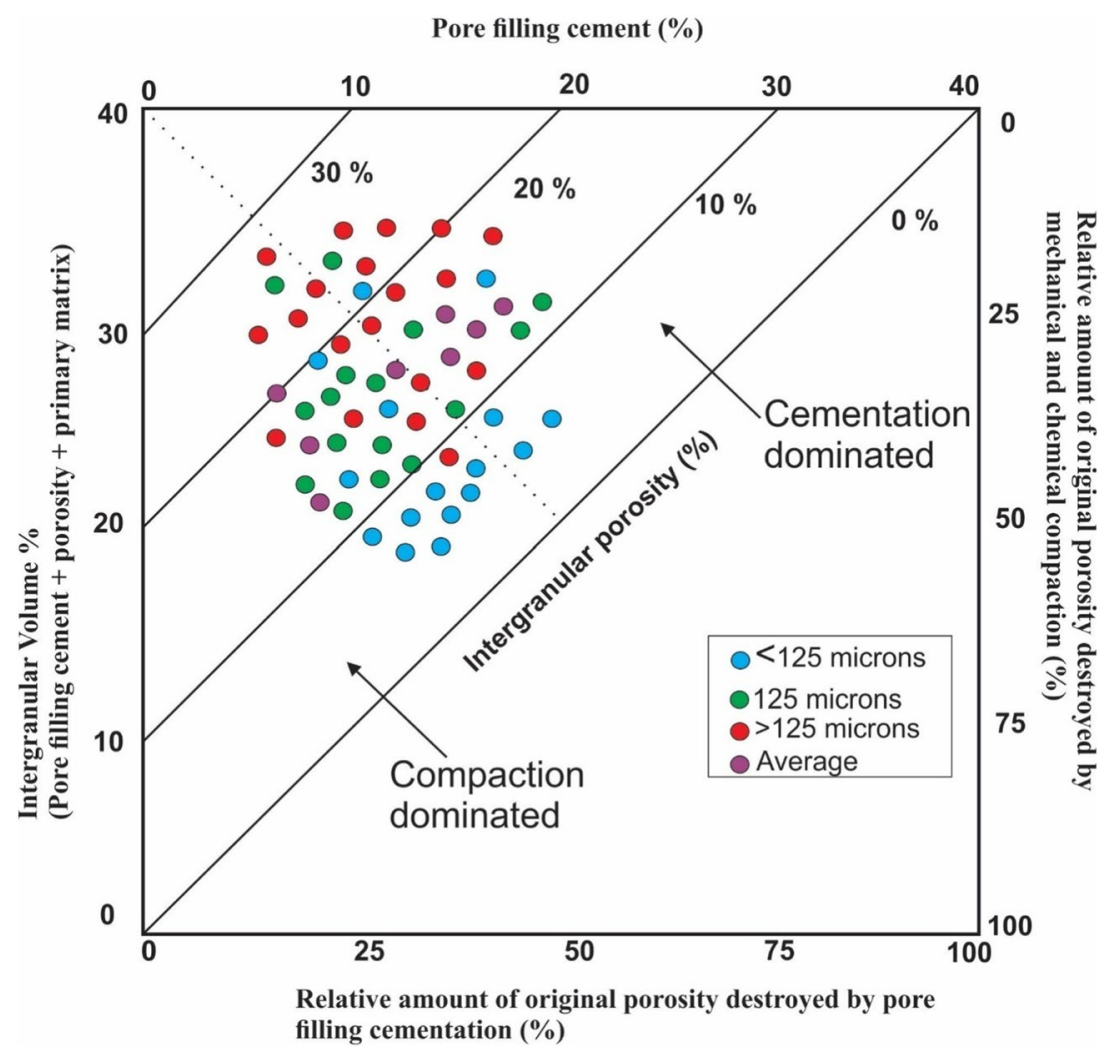


cementation as observed in SEM analysis. According to XRD analysis chlorite is the dominant clay mineral in the Lower Goru sandstone. Chlorite coating is one of the most important diagenetic features of the Lower Goru sandstone. Sandstone with chlorite cementation normally has high porosity and permeability (Baig 2016). Evidence from the Lower Goru sandstone suggests that pore-lining chlorite can grow by direct precipitation from pore water without precursor clay rims (Berger 2009).

Similarly, pores are filled by quartz overgrowth, causing reduction in porosity, and pore throats are affected by overgrowth edges which cause the reduction in the permeability (Fig. 8a-b).

The feldspar and other unstable grains dissolution played a fundamental role in the formation and development of secondary porosity in the sandstone (Fig. 7ab). With an increase in burial depth, pressure and temperature, and water chemistry porosity and permeability were decreased by precipitation of authigenic minerals (Fig. 8b).

Even though carbonate cement is observed in a minor amount in the Lower Goru sandstone reservoir and has a strong control on reservoir quality, carbonate cement causes a reduction of porosity and permeability of the sandstone reservoir. The depositional environment is one of the major elements governing the reservoir quality of a sandstone grain size, texture, matrix, framework grains, and mineralogical composition are directly related to the environment of deposition of the reservoir sandstone (Bjørlykke 2014). The Lower Goru sandstone has undergone strong compaction, cementation, therefore, producing dissolution pores as well as intercrystalline microspores. Diagenetic evolution of sediments has undergone the processes of mechanical compaction cementation, dissolution, and rock pores have undergone dramatic primary intergranular pore reduction early cementation development of secondary pores in large amount cementation in late stage.

\section{Conclusions}

The petrographic analysis of the investigated samples shows that detrital grains of the Early Cretaceous Lower Goru Sandstone are dominated by quartz, feldspar, rock fragments, glauconite, and micas and sandstones are fine to medium grained and moderately to well sorted. The identified cement are quartz, ferroan calcite, dolomite and anhydrite, and clay minerals. Based on petrographic studies the sandstone is categorized as arkose and lithic arkose.

Petrographic and SEM analysis revealed that the pore structure is predominantly composed of primary intergranular macropores, secondary intergranular macropores, and intercrystalline micropores. The reservoir sandstone has a maximum porosity of $20 \%$ and an average of $12 \%$, while permeabilities $0.04-0.24 \mathrm{MD}$ are very low.

The Lower Goru sandstone experienced considerable diagenetic variations like mechanical compaction, chlorite cementation, dissolution of feldspar, carbonate cementation, quartz cementation, and clay mineral alteration. The reservoir properties of the Lower Goru sandstone have been significantly affected by diagenesis. Diagenesis has influenced the porosity and permeability of the reservoir sandstone. Primary porosities including intergranular pores, intercrystalline pores, have been significantly reduced because of the strong mechanical compaction and authigenic cementation. Porosity is reduced mainly by chlorite, ferroan calcite, quartz, and clay matrix to a lesser extent. Chlorite cement was precipitated as grain rimming and pore occluding intergranular cement. The permeability of the sandstone reservoir has been reduced because of pore blocking of the chlorite and quartz cement.

Acknowledgements The authors are grateful to the editor and reviewers for detailed review and suggestions that have greatly improved this manuscript. The authors are thankful to Director General of Petroleum Concessions of Pakistan DGPC for providing the well data and permission to conduct research at HDIP. The authors are grateful to management of the Hydrocarbon development institute of Pakistan (HDIP) for support to complete this research. We are sincerely thankful to Prof. Dr. Aftab Ahmed Butt for kind suggestions. We are thankful to Hafiz Muhammad Tahir Javaid Senior Geologist from Pakistan Petroleum Limited for valuable suggestions. Funding for this work was provided by the Natural Science Foundation of China grant (No: 41390451).

Author contributions QUZZD designed this research and collected the relevant literature. PR supervised this study and provide access to lab facilities. CB help in petrographic analysis. GS provides petrographic analysis and diagenesis analysis. RIA provides software support for this study. UA provided help in diagenetic sequence study. ZS provide help in XRD analysis and MM provide interpretation of data.

Funding Natural Science Foundation of China provided financial support for this work through the Grant No (No: 41390451).

\section{Declarations}

\section{Conflict of interest None.}

Open Access This article is licensed under a Creative Commons Attribution 4.0 International License, which permits use, sharing, adaptation, distribution and reproduction in any medium or format, as long as you give appropriate credit to the original author(s) and the source, provide a link to the Creative Commons licence, and indicate if changes were made. The images or other third party material in this article are included in the article's Creative Commons licence, unless indicated otherwise in a credit line to the material. If material is not included in the article's Creative Commons licence and your intended use is not permitted by statutory regulation or exceeds the permitted use, you will need to obtain permission directly from the copyright holder. To view a copy of this licence, visit http://creativecommons.org/licenses/by/4.0/. 


\section{References}

Afzal J et al (2009) Seismic and Well-log Based Sequence Stratigraphy of The Early Cretaceous, Lower Goru "C" Sand of The Sawan Gas Field, Middle Indus Platform, Pakistan. Proceedings, Society of Petroleum Engineers (SPE)/Pakistan Association of Petroleum Geoscientists (PAPG) Annual Technical Conference, Islamabad, Pakistan

Ahmad N et al (2004) "Sequence stratigraphy as predictive tool in lower goru fairway, lower and middle Indus platform, Pakistan." PAPG, ATC: $85-104$

Ahmed W et al (2013) Mesozoic structural architecture of the middle Indus Basin, Pakistan-controls and implications. PAPG/SPE annual technical conference, Islamabad, Pakistan

Ali $\mathrm{M}$ et al (2021) Machine learning-a novel approach of well logs similarity based on synchronization measures to predict shear sonic logs. J Pet Sci Eng 203:108602

Ali, et al (2020) Building a rock physics model for the formation evaluation of the Lower Goru Sand Reservoir of the Southern Indus Basin in Pakistan. J Pet Sci Eng. https://doi.org/10.1016/j.petrol. 2020.107461

Ashraf U et al (2016) Analysis of Balkassar area using velocity modeling and interpolation to Affirm Seismic interpretation, Upper Indus Basin. Geosciences 2016(6):78-91

Ashraf U et al (2019) Classification of reservoir facies using well log and 3D seismic attributes for prospect evaluation and field development: a case study of Sawan gas field, Pakistan. J Petrol Sci Eng 175:338-351

Ashraf U et al (2020a) Application of unconventional seismic attributes and unsupervised machine learning for the identification of fault and fracture network. Appl Sci 10(11):3864

Ashraf U et al (2020b) Controls on reservoir heterogeneity of a Shallow-Marine Reservoir in Sawan gas field, Se Pakistan: implications for reservoir quality prediction using acoustic impedance inversion. Water 12(11):2972

Ashraf U et al (2021) A core logging, machine learning and Geostatistical Modeling interactive approach for subsurface imaging of lenticular geobodies in a clastic depositional system, SE Pakistan. Nat Resour Res 30(3):2807-2830

Bahlis AB, De Ros LF (2013) Origin and impact of authigenic chlorite in the Upper Cretaceous sandstone reservoirs of the Santos Basin, eastern Brazil. Pet Geosci 19(2):185-199

Baig MO, Harris NB, Ahmed H, Baig MOA (2016) Controls on reservoir diagenesis in the Lower Goru sandstone formation, Lower Indus Basin, Pakistan. J Pet Geol 39(1):29-47

Baiyegunhi $C$ et al (2017) Diagenesis and reservoir properties of the permian Ecca Group sandstones and mudrocks in the Eastern Cape Province, South Africa. Minerals 7(6):88

Berger A et al (2009) Porosity-preserving chlorite cements in shallow-marine volcaniclastic sandstones: evidence from Cretaceous sandstones of the Sawan gas field, Pakistan. AAPG Bull 93(5):595-615

Bjørlykke K (2011) Open-system chemical behaviour of Wilcox Group mudstones. How is large scale mass transfer at great burial depth in sedimentary basins possible? A discussion. Mar Pet Geol 7(28):1381-1382

Bjørlykke K (2014) Relationships between depositional environments, burial history and rock properties. Some principal aspects of diagenetic process in sedimentary basins. Sed Geol 301:1-14

Bjørlykke K, Egeberg P (1993) Quartz cementation in sedimentary basins. AAPG Bull 77(9):1538-1548

Bjørlykke K, Jahren J (2012) Open or closed geochemical systems during diagenesis in sedimentary basins: constraints on mass transfer during diagenesis and the prediction of porosity in sandstone and carbonate reservoirs. AAPG Bull 96(12):2193-2214
Bjørlykke K et al (1988) Modelling of thermal convection in sedimentary basins and its relevance to diagenetic reactions. Mar Pet Geol 5(4):338-351

Boggs S Jr, Boggs S (2009) Petrology of sedimentary rocks. Cambridge University Press

Cantarero I et al (2020) Fracturing and near-surface diagenesis of a silicified miocene deltaic sequence: The montjuïc hill (Barcelona). Minerals 10(2): 135

Chen G, Guichao Du, Zhang G, Wang Qi, Lv C, Chen Ji (2011) Chlorite cement and its effect on the reservoir quality of sandstones from the Panyu low-uplift, Pearl River Mouth Basin. Pet Sci $8(2): 143-150$

Chiang T, Ding S (2013) Physicochemical properties of radiopaque dicalcium silicate cement as a root-end filling material in an acidic environment. Int Endod J 46(3):234-241

Dar QUZ, Renhai P, Ghazi S, Ahmed S, Ali RI, Mehmood M (2021) Depositional facies and reservoir characteristics of the Early Cretaceous Lower Goru Formation, Lower Indus Basin Pakistan: Integration of petrographic and gamma-ray log analysis. Petroleum

Dickinson WR et al (1979) Mesozoic lithic sandstones in central Oregon. J Sediment Res 49(2):501-516

Dickinson WR et al (1983) Provenance of North American Phanerozoic sandstones in relation to tectonic setting. Geol Soc Am Bull 94(2):222-235

Ahmed AR et al (2010) Comparison of Core/Log and Well Test Permeabilities-A Closer Look" Sawan Tight Sands". SPE/PAPG Annual Technical Conference, Society of Petroleum Engineers

Folk RL et al (1970) Detrital sedimentary rock classification and nomenclature for use in New Zealand. N Z J Geol Geophy 13(4):937-968

Folk RL (1974) "Petrology of sedimentary rocks: Austin." Texas, Hemphill 182

Gier S et al (2008) Diagenesis and reservoir quality of Miocene sandstones in the Vienna Basin, Austria. Mar Pet Geol 25(8):681-695

Houseknecht DW (1988) Intergranular pressure solution in four quartzose sandstones. J Sediment Res 58(2):228-246

Hyodo A et al (2014) Evolution of quartz cementation and burial history of the Eau Claire Formation based on in situ oxygen isotope analysis of quartz overgrowths. Chem Geol 384:168-180

Islam MA (2009) Diagenesis and reservoir quality of Bhuban sandstones (Neogene), Titas gas field, Bengal Basin, Bangladesh. J Asian Earth Sci 35(1):89-100

Jamil, A., et al. (2012). "Pakistan's major petroleum plays-an overview of dwindling reserves." Search and Discovery, 10399: 1-2

Kadri I (1995) Petroleum Geology of Pakistan: Pakistan Petroleum Limited Karachi, Pakistan.

Khalid P et al (2014) Data-driven sequence stratigraphy of the Cretaceous depositional system, Punjab Platform, Pakistan. Surv Geophys 35(4):1065-1088

Krois P et al (1998). Miano field, Pakistan, A case history of model driven exploration. In: Proceedings Pakistan Petroleum Convention 98, Islamabad 25-26 November, Pakistan Association of Petroleum Geoscientists (PAPG) Islamabad, Pakistan

Mahmoud, S. (2015). Integrated sequence stratigraphy of the Cretaceous Lower Goru Deposits, Lower Indus Basin, Pakistan. In: International conference and exhibition

Makeen YM et al (2016) Sedimentology, diagenesis and reservoir quality of the upper Abu Gabra Formation sandstones in the Fula Sub-basin, Muglad Basin, Sudan. Mar Pet Geol 77:1227-1242

Mangi HN et al (2020) Pore structure characteristics and fractal dimension analysis of low rank coal in the Lower Indus Basin, SE Pakistan. J Nat Gas Sci Eng 77:103231

Morad S et al (2010) The impact of diagenesis on the heterogeneity of sandstone reservoirs: a review of the role of depositional facies and sequence stratigraphy. AAPG Bull 94(8):1267-1309

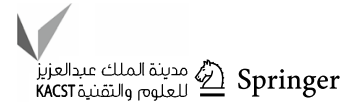


Naeem M et al (2016) Seismic and well log driven structural and petrophysical analysis of the Lower Goru Formation in the Lower Indus Basin, Pakistan. Geosci J 20(1):57-75

Paxton S et al (2002) Construction of an intergranular volume compaction curve for evaluating and predicting compaction and porosity loss in rigid-grain sandstone reservoirs. AAPG Bull 86(12):2047-2067

Pettijohn DE et al (1987) Glycoproteins distinguishing non-small cell from small cell human lung carcinoma recognized by monoclonal antibody 43-9F. Can Res 47(4):1161-1169

Pittman ED, Larese RE (1991) Compaction of lithic sands: experimental results and applications. AAPG Bull 75(8):1279-1299

Qadri ST, Islam MA, Shalaby MR (2019) Application of well log analysis to estimate the petrophysical parameters and evaluate the reservoir quality of the Lower Goru Formation, Lower Indus Basin, Pakistan. Geomech Geophys Geo-Energy Geo-Resour 5(3):271-288

Qureshi MA et al (2021) Geo-seismic model for petroleum plays an assessment of the Zamzama area, Southern Indus Basin, Pakistan. J Pet Explor Prod 11(1):33-44

Robison C et al (1999) Organic facies in Cretaceous and Jurassic hydrocarbon source rocks, Southern Indus basin, Pakistan. Int J Coal Geol 39(1-3):205-225

Sajid Z, Ismail MS, Zakariah MNA, Tsegab H, Gámez Vintaned JA, Hanif T, Ahmed N (2020) Impact of Paleosalinity, Paleoredox, Paleoproductivity/Preservation on the Organic Matter Enrichment in Black Shales from Triassic Turbidites of Semanggol Basin, Peninsular Malaysia. Minerals 10(10):915

Schmidt V, McDonald DA (1979) The role of secondary porosity in the course of sandstone diagenesis. https://doi.org/10.2110/pec. 79.26.0175
Worden R, Morad S (2003) Clay minerals in sandstones: controls on formation, distribution and evolution. Spec Publ Int Assoc Sedimentol 34:3-42

Xi K et al (2015) Diagenesis and reservoir quality of the Lower Cretaceous Quantou Formation tight sandstones in the southern Songliao Basin, China. Sed Geol 330:90-107

Yasin Q et al (2017) Impact of organic contents and brittleness indices to differentiate the brittle-ductile transitional zone in shale gas reservoir. Geosci J 21(5):779-789

Yasin Q, Du Q, Ismail A, Shaikh A (2019) A new integrated workflow for improving permeability estimation in a highly heterogeneous reservoir of Sawan Gas Field from well logs data. Geomech Geophys Geo-Energy Geo-Resour 5(2):121-142

$\mathrm{Yu}$ Y et al (2019) Impacts of lithologic characteristics and diagenesis on reservoir quality of the 4th member of the Upper Triassic Xujiahe Formation tight gas sandstones in the western Sichuan Basin, southwest China. Mar Pet Geol 107:1-19

Zaigham NA, Mallick KA (2000) Prospect of hydrocarbon associated with fossil-rift structures of the southern Indus basin, Pakistan. AAPG Bull 84(11):1833-1848

Zhang Y et al (2020) Geological characteristics and abnormal pore pressure prediction in shale oil formations of the Dongying depression, China. Energy Sci Eng 8(6):1962-1979

Publisher's Note Springer Nature remains neutral with regard to jurisdictional claims in published maps and institutional affiliations. 